THE KURUME MEDICAL JOURNAL Vol. 2, No. 1, 1955

\title{
STUDIES ON THE INFLUENCE UPON THE SUSCEPTIBILITY OF MICE TO VIRUS II Report.
}

Effect of cortisone on the susceptibility of mice to virus (2)

\author{
YOH NAKAGAWA AND YUKISHIGE KANDA \\ Department of Bacteriology, Kurume University School \\ of Medicine, Kurume-shi, Japan
}

In the previous report (1) we confirmed that relatively large dose of cortisone, when employed as a preliminary treatment, had promoted the susceptibility of mice to mouse encephalomyelitis virus. As cortisone shows a very wide action, an unitary understanding on the mechanism of its action has not yet been reached in spite of many studies. Therefore, at the present time the mechanism of the susceptibility increasing effect of cortisone to virus is still unknown. As we pointed out in the previous report, cortisone promoted not only the susceptibility of mice to virus but also the susceptibility to all common bacteria, so a possibility that a single medicine works on various different pathogenic microorganisms is considered to be very little. Southan et al (2) concluded that infection promoting eflect of cortisone must have been the action on the host and we think that this point is quite right.

We understand quite well that adrenal cortex plays an important role on maintaining life, but we are very doubtful that cortisone shows very wide action. So we would like to conceive that cortisone may cause a chain reaction in living bodies. In order to solve this problem there is no other means but to study step by step. We believe that the solution of this problem will serve a great deal for analysis of virus susceptibility.

In this report, we wish to report the result on the effect of cortisone upon the multiplication of virus in the brain and the condition of mice at the time of administeration of cortisone.

\section{EFFECT OF CORTISONE ON THE MULTIPLICATION OF VIRUS IN THE MOUSE BRAIN}

\section{Materials and Methods}

Virus: Mouse encephalomyelitis virus (GDV1l strain) used in this experiment was obtained from Dr. Rustigian of Chicago University. 
Mouse: Healthy mice of 3 or 4 weeks-old (weighing about $10 \mathrm{~g}$ ) were used and they were taken care of so as to maintain as same condition as possible.

Cortisone and its administration: Cortisone used in this experiment was cortone acetate (Merck) and daily dose of $0.5 \mathrm{mg}$ was intramuscularly administered for 4 days. Matters that demand special attention were already described in the first report.

Experimental methods: (1) 10 mice were prepared. Cortisone was administered to 5 of them and another 5 were remained as control. $0.03 \mathrm{cc}$ of the infected mouse brain emulsion diluted to $10^{-6}$ was inoculated into the brain of each mouse. These mice were killed after 4 days and their brains were harvested. The infectivity $\left(\mathrm{LD}_{50}\right)$ of the brains of each group was titrated and the rate of virus multiplication was compared. (2) In the next experiments virus was intraperitoneally inoculated. 32 mice were prepared, cortisone was administered to 16 of them and another 16 mice were remained as control. $0.2 \mathrm{cc}$ of the infected mouse brain emulsion diluted to $10^{-2}$ was intraperitoneally inoculated, 4 mice of each group were killed every 24 hours. Their brains were removed out and the rate of virus multiplication was compared by titrating of $\mathrm{LD}_{50}$.

\section{Experimental Results}

(1) $\mathrm{LD}_{\overline{0} 0}$ of the treated group with cortisone was $10^{-6.0}$ while that of the control group was $10^{-4.8} 4$ days after the intracerebral inoculation of the virus. (2) The results obtained from the experiments in which mice were intraperitoneally inoculated with the virus are shown in Table 1 . Any infectivity was not shown at

TABLE 1

Effect of cortisone on the multiplication of the virus in the brain

\begin{tabular}{c|c|c|c|c|c}
\hline \multicolumn{2}{c|}{ Days after inocul.* } & 1 & 2 & 3 & 4 \\
\hline \multirow{2}{*}{$\mathrm{LD}_{50}$} & treated & $<10^{-1}$ & $10^{-3.3}$ & $10^{-5.6}$ & $10^{-62}$ \\
\cline { 2 - 6 } & controls & $<10^{-1}$ & $10^{-2.1}$ & $10^{-4.1}$ & $10^{-4.8}$ \\
\hline \multicolumn{2}{c|}{ Log diff. } & & 1.2 & 1.5 & 1.4 \\
\hline
\end{tabular}

* intraperitoneal inoculation. 24 hours after the inoculation: $L_{50}$ of the treated group with cortisone was $10^{-3.3}$ after 2 days while that of the control group was $10^{-2.1}$ and $\mathrm{LD}_{50}$ of the treated group was $10^{-5.6}$ after 3 days while that of the control group was 10 $0^{-4.1}$. After 4 days, $\mathrm{LD}_{50}$ of the treated group was $10^{-6.2}$ while that of the control group was $10^{-4.8}$. From these results it was considered that cortisone promoted the multiplication of virus in the mouse brain. 


\section{EFFECT OF CORTISONE ON THE INFLAMMATORY REACTION}

\section{A. Effect on the progress of inflammatory response in the brain at the early stage of infection}

\section{Materials and Methods}

Mouse: 2 groups were prepared. One group was consisted of 5 mice to which virus was inoculated after administrating daily $0.5 \mathrm{mg}$ of cortisone intramuscularly for 4 days. The another group was also consisted of 5 mice to which virus alone was inoculated. Virus inoculation was done by giving $0.2 \mathrm{cc}$ of the infected mouse brain emulsion diluted to $10^{-2}$ intraperitoneally. In order to obtain an accurate experimental result and to serve for the judgement, another 3 groups of mice were also prepared, namely, a group of non-treated mice, of mice inoculated with the virus and left to show a typical clinical symptom, and of mice treated with cortisone alone.

Experimental methods: Mice were killed on the 3rd day after inoculation of virus before they showed any clinical symptom. Brains were removed out, fixed as usual, inbeded in celloidin, stained by Nissl's method and their inflammatory reactions were observed.

\section{Experimental Results}

A study was made on the rate of an early inflammatory reaction in the brains of the treated mice with cortisone and the control mice. Significant changes were not confirmed in all examples of the control group. Only a progressive form of the Hortega cells was found in the brains of cortisone-treated mice in which virus multiplied more markedly than control. No change were observed in the brains of mice which were treated with cortisone alone.

\section{B. Effect on the skin inflammatory response caused by turpentine oil}

\section{Materials and Methods}

Mouse and preliminary treatment: 2 groups which were consisted of 5 mice respecitively were prepared. One of these groups was administered daily $0.5 \mathrm{mg}$ of cortisone for 3 days and another group was a non-treated group. The hair on the back of these mice was trimmed by scissors and Eva cream (depilatory) was coated and a depilated space of about $1 \mathrm{~cm}$ square was made. 
Method of injection of turpentine oil: Air pouch was made in the subcutaneous region of the depilated space by injecting $0.3 \mathrm{cc}$ of air and $0.05 \mathrm{cc}$ of sterilized turpentine oil was injected.This method was modified from granuloma pouch of Selye (24).

\section{Experimental Results}

The results are shown in Table 2. The group without any administration of cortisone showed a remarkable inflammatory response 2 days after the injection of turpentine oil. Namely, the reddening was observed macroscopically, exsudate

TABLE 2

Effect of cortisone on the course of inflammation caused by turpentine oil

\begin{tabular}{c|cccccc|ccccc}
\hline cortiosne & course & \multicolumn{4}{|c|}{$\begin{array}{l}\text { Days to inflam- } \\
\text { matory response }\end{array}$} & \multicolumn{5}{c}{$\begin{array}{c}\text { Days to } \\
\text { crust }\end{array}$} \\
\hline $0.5 \mathrm{mg}$ & 3 days & 4 & 5 & 5 & 5 & 5 & 14 & 14 & 14 & 15 & 16 \\
\hline 0 & 2 & 2 & 2 & 2 & 2 & 8 & 8 & 8 & 9 & 9 \\
\hline
\end{tabular}
was deposited, and suppuration was caused. A crust was formed after 8 or 9 days.

On the contrary, the mice treated with cortisone delayed appearance of inflammatory response

2 to 4 days longer than the former, and its process also remarkably delayed. Series of inflammatory reaction process were shown in Photograph 1.

\section{EFFECT OF CORTISONE UPON THE ANTIBODY IN BLOOD}

\section{A. Effect on the antibody formation}

\section{Materials and Methods}

Formation of hemagglutination inhibition antibody on human 0 type erythrocytes was fixed as the index.

Mouse and the collcction of serum: (1) First 2 groups were prepared as control groups. One of these groups was administered daily $1.0 \mathrm{mg}$ of cortisone for 2 days but not immunized. The other group was a non treated group. Then another 2 groups were also prepared. One of these groups was once immunized intraperitoneally with $0.3 \mathrm{cc}$ of the infected mouse brain emulsion diluted to $10^{-4}$ after administration of cortisone. The other group received immnization alone. 4 groups were thus prepared with 16 mice in each group. Blood was collected from 4 mice of each group 4, 7 and 10 days respectively after the last injection of cortisone or immunization. Serum was then isolated and was diluted to 8-fold with saline solution. This diluted serum was used after inactivating for 30 minutes 
at $56 \mathrm{C}$. (2) In order to explain the relation of the mechanism of promoting the multiplication of virus in the brain, $0.2 \mathrm{cc}$ of the infected mouse brain emulsion diluted to $10^{-2}$ was inoculated intraperitoneally to each 10 mice of the cortisone treated group and the non treated group. 3 and 4 days after this inoculation of virus blood was collected from each 5 mice of the 2 groups including the mice that were shown clinical symptoms. Serum thus obtained was used for the experiment.

Hemagglutination inhibition test: $0.3 \%$ suspending solution of 0 type human erythrocytes used in this reaction was made with saline solution. Standared solution of the virus used in this reaction was purified by the following methods: equal volume of a $10 \%$ suspending solution of erythrocytes was added to a $10 \%$ infected mouse brain emulsion and the mixture was kept at $4 \mathrm{C}$ and shaken well for an hour at intervals of 10 minutes. After keeping it still for 12 hours at $4 \mathrm{C}$, erythrocytes was isolated by low speed centrifugation. Then it was diluted to the original volume with saline solution of $37 \mathrm{C}$ and was kept for 20 minutes at $37 \mathrm{C}$. The supernatant fluid obtained by centrifugation was used for the test. Another method was conducted in accordance with Hirst test but the reacting temperature was $4 \mathrm{C}$.

\section{Experimental Results}

(1) The results are shown in Table 3. In normal mouse serum there exists a normal inhibitor having 32 to 64 of inhibiting titers. No effects have been observed in the quantity of normal inhibitor caused by administration of cortisone. The immune group which was not treated with cortisone showed a production of hemagglutination inhibition antibody affer 7 days and showed $2 \overline{5} 6$ inhibiting titers after 10 days. The immune group which was treated with cortisone showed no production of inhibition antibody up to 10 days. Thus it was made clear that cortisone acted so as to decrease antibody formation. (2) In the experiment about serum collected 3 and 4 days after inoculation of the virus, infected mouse brain emulsion diluted to $10^{-2}$

TABLE 3

Effect of cortisone upon antibody formation

\begin{tabular}{|c|c|c|c|c|c|}
\hline \multirow{5}{*}{ 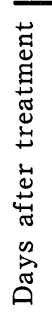 } & & \multicolumn{2}{|c|}{ nonimmunized } & \multicolumn{2}{|c|}{ immunized ${ }^{*}$} \\
\hline & & treated & normal & treated & control \\
\hline & 4 & $64^{* * *}$ & 64 & 64 & 64 \\
\hline & 7 & 64 & 32 & 64 & 128 \\
\hline & 10 & 64 & 64 & 64 & 256 \\
\hline
\end{tabular}


intraperitoneally, it was observed inhibition antibodies 128 titers were produced in the serum of the mice which were non-treated with cortisone, while the inhibiting titers were 64 in other mice which were treated with cortisone and, therefore, antibody formation was not observed. It was made clear that the mechanism of promoting the multiplication of virus in the brain by cortisone precedes both the antibody formation and appearance of hindering effect of cortisone on its production.

\section{B. Effect on the existing antibody}

\section{Materials and Methods}

The method of hemagglutination inhibition test was the same as that of the previous experiment.

Mouse and scrum collcction: 45 mice were immunized by intraperitoneal inoculation of $0.3 \mathrm{cc}$ of the infected mouse brain emulsion diluted to $10^{-4}$. Serum was collected from 4 mice 10 days after. and its antibody titers were measured, and it was shown that the inhibiting titers were 256. At this time 40 mice were divided into 2 groups, the control group and the experimental group to which $1.5 \mathrm{mg}$ of cortisone was given daily for 3 days. Serum was collected from 5 mice

TABLE 4

Effect of cortisone on the existing antibody

\begin{tabular}{|c|c|c|c|}
\hline \multirow{3}{*}{ 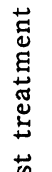 } & \multirow[b]{2}{*}{0} & treated & control \\
\hline & & $256 \times$ & $256 \times$ \\
\hline & 1 & *256 $\times$ & $256 \times$ \\
\hline 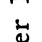 & 2 & ${ }^{* *} 256 \times$ & $256 \times$ \\
\hline (1) & 3 & $* * * 256 \times$ & $256 \times$ \\
\hline$\stackrel{\pi}{\Delta}$ & 4 & $256 \times$ & $256 \times$ \\
\hline
\end{tabular}
of each group daily beginning from 24 hours after the first administration of cortisone. Effects on inhibition antibodies in serum were thus observed for 4 days.

\section{Experimental Results}

The results are shown in Table 4. Cortisone did not show any direct effect on the quantity of the existing antibodies. But at the autopsy of the mice, atrophy of the spleen and that of the lymph tissue were observed at 24 hours after administration of cortisone.

\section{EFFECT ON THE FUNCTION OF R.E. SYSTEM}

\section{Materials and Methods}

Mouse: 3 groups were prepared. The first group was consisted of mice to which $1.0 \mathrm{mg}$ of cortisone was administered daily for 2 days, the second group was consisted of mice to which $0.05 \mathrm{mg}$ of cortisone warsadministe ed daily for 4 days, 
and the third group was consisted of non-treated mice. Function of $\mathrm{R}$ E. system of these groups were tested 48 hours after the last administration of cortisone. Every time 3 mice were used as a unit.

Testing method: Phagocytic function test (25) by india ink granules in subcutaneous tissue cells was adopted for testing the function of R.E. system.

First, subcutaneous tissue was cut off from the back of the mice with attention to infection. This was put into sterilized petri dish containing india ink diluted in Ringer solution. Then, diluted india ink was injected into the tissue with a small syringe. But this injection is unnecessary if the piece of tissue is small because a good result can be obtained by only soak. Further this tissue was left for 2.5 hours at $37 \mathrm{C}$ and was put into 2,000 times diluted neutral red saline solution and was vitally stained for 30 minutes at $37 \mathrm{C}$. Small pieces were cut off from the tissue and extended and the phagocytic function to indea ink granules were observed by means of microscopy.

Rate of the phagocytic function was divided into 4 grades by number of the histiocytic cells which showed a distinct phagocytic function, in another word, which included a great amount of fine india ink granules or had a distinct large round ink granule and a small amount of neutral red granules. When a phagocyte like this was found in $2-3$ cells the grade was shown as (H), when a phagocyte was found in 4-6 cells ( 4$)$, when a phgocyte was found in over 7 cells $(+)$, and when none of phgocyte like this was found (-). And this test was applied to the following 2 cases. (1) The above test was applied on the fresh subcutaneous tissue removed from the mice and a comparative observation was carried out. (2) Continuance of the phagocytic function of subcutaneous tissue cells was compared in the case when mice were killed and carcass kept at $37 \mathrm{C}$.

Preparation of the india ink granules suspension: An ink-stick was rubbed in Akama ink-slab with Ringer solution. Original india ink solution was prepared by filtrating twice through filter paper. And the original ink was

Figure 1.

Effect of cortisone on the phagocytic function subcutaneous tissue-cells. (in case of the carcass kept in $37 \mathrm{C}$ )

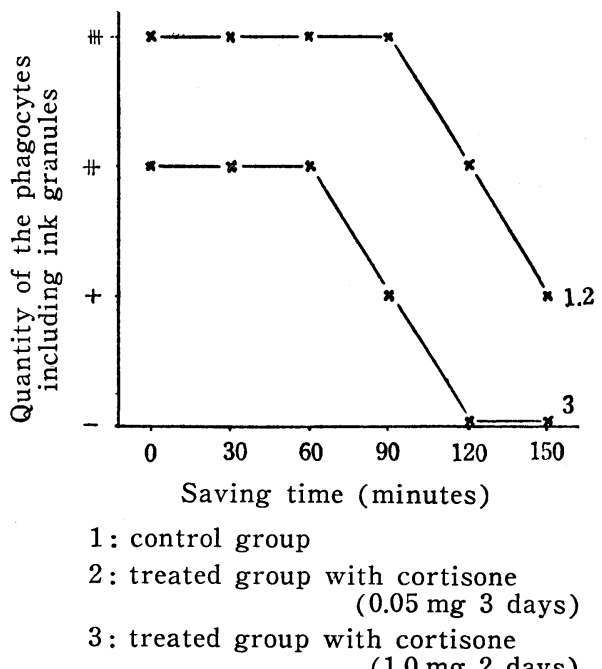


diluted with Ringer solution to a degree that a black line was scarcely visible through the thickness of $5 \mathrm{~mm}$ of the solution.

\section{Experimental Results}

The results are shown in Fig. 1. In the group of mice to which $1.0 \mathrm{mg}$ of cortisone was administered daily for 2 days, decrease of phagocytic function was clearly observed compared with the group of mice to which $0.05 \mathrm{mf}$ of cortisone was administered daily for 4 days and with the group of the non-treated mice. Concerning the continuance of the phagocytic function, a distinct phagocytic figure was observed even after 150 minutes in the mice to which $0.05 \mathrm{mg}$ of cortisone were administered daily for 4 days and in the non-treated mice. On the other hand the mice to which $1.0 \mathrm{mg}$ of cortisone were administered daily for 2 days showed the same grade of phagocytic figure after 90 minutes as shown in the former 2 groups after 120 minutes. It was made clear that function of R.E. system can be decreased by administration of effective amount of cortisone to increase the susceptibility.

\section{ON THE SPECIFIC ANATOMICAL CHANGES OF CORTISONE TREATED MICE}

\section{Materials and Methods}

Mouse: 3 groups were prepared. The first group was consisted of 16 mice to which $1.0 \mathrm{mg}$ of cortisone was administered daily for 2 days and $0.2 \mathrm{cc}$ of the infected mouse brain emulsion diluted to $10^{-3}$ was inoculated intraperitoneally. The second group was also consisted of 16 mice to which the virus alone was inoculated. The third was a control group consisted of normal mice.

Observating method: 4 mice were killed 48 hours, 72 hours, 96 hours and 120 hours respecitively after the inoculation of the virus and an anatomical changes were observed. Spleen, liver, kidny, adrenal and heart were weighed. Further liver and atrophic spleen were observed histologically.

\section{Experimental Results}

The results obtained in cortisone treated mice are shown in Fig. 2 and Photo. 2. The remarkable change was the atrophy of the spleen decreasing the weight to nearly one third of the control, while the spleen of the mice to which virus alone was inoculated showed a tendency of enlargement. A remarkable atrophy of lymph gland was also observed. No distinct difference was observed in the weight 
of other various organs compared with of the non-treated mice. The weight of each organ 96 hours after the inoculation of virus was shown in Table 5. Each weight shows the total weight of organs of 4 mice. After histological examination of liver and atrophic spleen, it was found that there occurred no distinct change in liver compared with that of the non-treated mice and that atrophic spleen showed remarkable atrophy of lymph follicle as shown in Photo. 3.

\section{TABLE 5}

Anatomic change produced in mice treated with cortisone (2)

\begin{tabular}{c|c|c}
\multicolumn{2}{c}{ Weight of various organs } \\
\hline organ & untreated & treated \\
\hline liver & $1310 \mathrm{mg}$ & $1295 \mathrm{mg}$ \\
\hline kidney & $295 \mathrm{mg}$ & $300 \mathrm{mg}$ \\
\hline adrenal & $2.5 \mathrm{mg}$ & $2.1 \mathrm{mg}$ \\
\hline heart & $87 \mathrm{mg}$ & $88 \mathrm{mg}$ \\
\hline
\end{tabular}

The results are shown the weight of each 4 organs.

Figure 2.

Anatomic change produced in mice treated with cortisone (1).

Change of the weight of the spleen.

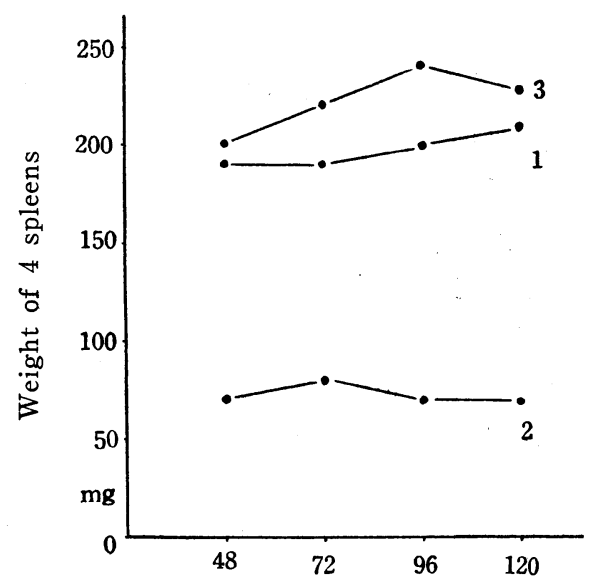

Hours after treatment or inoculation

1: normal mice

2: treated mice with cortisone

3 : untreated mice but inoculated by virus

\section{EFFECTS ON THE BLOOD SUGAR LEVEL AND ON THE SERUM PROTEIN}

\section{Materials and Methods}

Mouse: 3 groups were prepared. The first was the group to which $1.0 \mathrm{mg}$ of cortisone was administered daily for 2 days. The second was the group to which $0.05 \mathrm{mg}$ of cortisone was administered daily for 2 days. The third was the group of non-treated mice. These 3 groups were tested at 24 hours and 72 hours after the administration of cortisone. Another 2 groups which were inoculated intraperitoneally with $0.2 \mathrm{cc}$ of the infected mouse brain emulsion diluted to $10^{-3}$ were also prepared. One of the two groups was administered daily $1.0 \mathrm{mg}$ of cortisone for 2 days before inoculation and the other was not treated with cortisone.

Testing method of the blood sugar level: Hagedorn-Jensen's method was used. Test was conducted once on 2 or 3 mice of each group separately and venous blood was used. 
Quantity of serum protein: It was reckoned from the gravity that obtained by cupper sulphate method. Serum used was collected from 5 mice of each group.

A/G Ratio: It was obtained after Yoshikawa \& Saito's method.

Quantity of hcmoglobin: Venous blood of each mouse was measured by Sahli's hemoglobinometer and its average was obtained.

\section{Experimental Methods}

Effect of cortisone on blood sugar level are shown in Table 6. Administration of cortisone which is effective to increase the susceptibility did not cause any remarkable change in blood sugar level within 72 hours and was not also affected by virus inoculation. No remarkable effects were also. observed in serum protein within 72 hours. Explaining it more in detail, after 96 hours, increase of quantity of the hemoglobin was observed in mice treated with cortisone and inoculated with virus. But as there was no decrease in the quantity of serum protein, there seemed to be an apperarance of transudation mechanism of water in blood. Increasing of globulin was observed in mice not treated with cortisone and inoculated

TABLE 6

Effect of cortisone on the blood sugar level

\begin{tabular}{|c|c|c|c|c|c|c|c|c|c|c|c|c|c|c|c|}
\hline \multirow{3}{*}{ 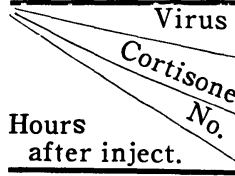 } & \multicolumn{9}{|c|}{ uninoculated } & \multicolumn{6}{|c|}{ inoculated } \\
\hline & \multicolumn{3}{|c|}{$1.0 \mathrm{mg} 2$ days } & \multicolumn{3}{|c|}{$0.05 \mathrm{mg} 2$ days } & \multicolumn{3}{|c|}{0} & \multicolumn{3}{|c|}{$1.0 \mathrm{mg} 2$ days } & \multicolumn{3}{|c|}{0} \\
\hline & 1 & 2 & 3 & 1 & 2 & 3 & 1 & 2 & 3 & 1 & 2 & 3 & 1 & 2 & 3 \\
\hline \multirow{2}{*}{24} & 81 & 99 & 92 & 92 & 81 & 77 & 81 & 99 & 88 & 93 & 93 & 89 & 93 & 98 & 98 \\
\hline & \multicolumn{3}{|c|}{ Arg. $91 \mathrm{mg} / \mathrm{dl}$} & \multicolumn{3}{|c|}{$83 \mathrm{mg} / \mathrm{dl}$} & \multicolumn{3}{|c|}{$89 \mathrm{mg} / \mathrm{dl}$} & \multicolumn{3}{|c|}{$92 \mathrm{mg} / \mathrm{dl}$} & \multicolumn{3}{|c|}{$96 \mathrm{mg} / \mathrm{dl}$} \\
\hline \multirow{2}{*}{72} & 88 & 79 & 93 & 93 & 84 & 84 & 88 & 81 & 90 & 96 & 98 & 108 & 88 & 101 & 98 \\
\hline & \multicolumn{3}{|c|}{ Arg. $86 \mathrm{mg} / \mathrm{dl}$} & \multicolumn{3}{|c|}{$87 \mathrm{mg} / \mathrm{dl}$} & \multicolumn{3}{|c|}{$86 \mathrm{mg} / \mathrm{dl}$} & \multicolumn{3}{|c|}{$101 \mathrm{mg} / \mathrm{dl}$} & \multicolumn{3}{|c|}{$96 \mathrm{mg} / \mathrm{dl}$} \\
\hline
\end{tabular}

TABLE 7

Effect of cortisone on the serum protein

\begin{tabular}{c|c|c|c|c|c|c|c|c|c}
\hline \multirow{2}{*}{ Cortisone } & \multicolumn{7}{|c|}{ Hours after inoculation } \\
\cline { 2 - 9 } & \multicolumn{2}{|c|}{24} & \multicolumn{2}{|c|}{48} & \multicolumn{2}{c}{96} \\
\hline $1.0 \mathrm{mg} 2$ days & $6.18 \mathrm{~g} / \mathrm{dl}$ & 1.2 & 85 & $6.18 \mathrm{~g} / \mathrm{dl}$ & 1.2 & 90 & $6.18 \mathrm{~g} / \mathrm{dl}$ & 1.2 & 92 \\
\hline 0 & $6.18 \mathrm{~g} / \mathrm{dl}$ & 1.2 & 85 & $6.18 \mathrm{~g} / \mathrm{dl}$ & 1.0 & 84 & $6.55 \mathrm{~g} / \mathrm{dl}$ & 0.9 & 84 \\
\hline
\end{tabular}


with virus but it was not observed in the mice treated with cortisone. But these do not precede the mechanism of increasing the multiplication of the virus in the brain. Only the results of the group to which virus alone was inoculated are shown in Table 7.

\section{DISCUSSION}

Concerning the mechanism of cortisone which showed the effect of increasing susceptibility of mice to mouse encephalomyelitis virus, as Smith et al (3) or Shwartzman et al (4) had already reported, the administration of cortisone which is effective to increase the susceptibility of mice to the virus promoted the multiplication of the virus in the brain. As we have mentioned in the previous report (1), the growth of mouse will be hindered by effective dose of cortisone, so this will not be in accordance with the general way of thinking that rickettsiae or comparative large viruses multiply well in the cell where metabolism is low and comparative small viruses multiply well in an energetic cell. But we are willing to discuss concerning this point in another report again. If it is difficult to think of pathogenity of the virus apart from virus particle, the increase of multiplication will come to possess an important meaning in the course of viral diseases. The increase of multiplication of cytotrophic virus, and if it is starting from non-viral component, seems to cause a change in metabolic system of virus susceptible cell. However, many unsolved questions are left on the factor which rules the multiplication of the virus. Further, how is the mechanism which controls this factor? What effect is the already known important actions of cortisone giving to this factor? These mutual relations should be made clear. If these points are made clear, it will serve to solve the problems of virus susceptibility and also solve the inner secretory protecting mechanism more widely. The susceptibility increasing effect of cortisone can be also observed in infection by common bacteria, so there seems to be an existence of a consistent mechanism of the action or a reactive system.

Therefore, when the way of thinking about the susceptibility is divided into the following two according to Kawakita (5), the receptivity and the vulnerability, the effect of cortisone is to increase the receptivity which allows the multiplication of pathogenic microorganism but an attention must be paid upon the vulnerability which rises the symptom as well. Michael et al (6) thought that cortisone would promote bacterial infection because it inhibit the inflammatory reaction. We made a histological observation of the effect of cortisone on the progress of an early inflammatory reaction of the mouse brains when the multiplication of 
virus in the brain of mice treated with cortisone and that of the control mice showed a distinct difference, but we could not observed any significant effects and in it was known, in general, that the appearance of cellular reaction was slow compared with the rate of multiplication of virus.

Effective dose of cortisone to increase the susceptibility will not directly show chromatolysis and vacuolation in nervous cell as Castor et al (7) pointed out previously. The virus multiplication promoting mechanism of cortisone has no relation with inhibiting effect of inflammatory reaction especially cellular reaction. It does not mean that this result causes any doubts on anti-inflammatory action of cortisone and it was made clear that an administration of cortisone delayed an appearance of skin inflammatory response caused by turpentine oil. A certain phase of the vulnerability was well shown by this result. As cortisone is said to show a symptom masking effect such as antipyretic action, cheerfulness and an increase of appetite, it seems to decrease the vulnerability. And study is beeing made from various points on anti-inflammatory mechanism of cortisone but nothing is known so far clearly. We will refrain from explaining on this problem in detail but we wish to add an importance to its relation of anti-mesenchymal action which cortisone shows.

(We should understand that, in general, the vulnerability is divided into the following two, local vulnerability and general vulnerability.)

Many reports have been made concerning the effect of cortisone on the antibody formation. It was reported by many workes (8) $\cdots$ (13) that it reduced the antibody formation, while other report (14) demonstrated that it had no effects and some other reports (15) (16) that it rather promoted the formation. Oyama (17) has observed that a proper amount of cortex hormone promotes the formation of antibody but an excess amount of it reduces the formation We also think that it will be controlled by the amount of cortisone but the orginal action of cortisone is shown by use of large quantity of that. In this experiment it is made clear that the effective administration of cortisone to increase the susceptibility reduces the antibody formation.

Based upon the opinion that the infection promoting effect of cortisone precedes the appearance of antigen antibody reaction, we were able to make it clear that the virus multiplication promoting mechanism of cortisone also preceded the formation of antibody or its hindering effect by cortisone. The increasc of virus multiplication, or in other words, the increase of the receptivity, seems to possess an important meaning in solving the consistent mechanism of action of cortisone. This problem should be much accounted because it plays an important role as 
a factor to control the susceptibility of viral disease as well as its prognosis. And this is quite certain in the case of neurotrophic virus infection. The importance of this point is backed up also by the fact that cortisone is effective to be used as a preliminary treatment of virus inoculation. Furthermore, although Dougherty reported that free antibody will be increased by destraction of lymphocytes caused by cortisone, we think this should be considered from different point as effect of cortisone on existing antibody. We were not able to obtain such results as Dongherty's in this experiment and by such administration of cortisone would not distinct effect on existing antibody be shown. The possibility of antigen antibody reaction caused by virus until the time the virus contacts with susceptible cell will not be changed even if cortisone is administered. For these reasons it is impossible to put a great weight upon the effect of cortisone on the immunity by antibody as the susceptibility increasing mechanism.

Concerning the function of R.E. system, in 1931 Reis and Gothe (18) reported that if adrenal extract was injected into animals, macrophage function would be increased, but cortisone which is a single purified hormone recently is known to decrease the function of R.E. system (17) (19) (20). The amount of used cortisone, of course, would be the problem in this case too. We made it clear in this experiment that an effective administration of cortisone to increase the susceptibility would decrease phagocytic function of subcutaneous tissue cells and the function of R.E. system accordingly decreased. Recently Thomas (20) made a report in which he tried to explain the susceptibility increasing effect of cortisone in infection by common bacteria by means of hypofunction of R.E. system. But if we consider the virus of very small size and its cytotrophism at the time of its infection, Metchnikoff's inflammatory concept seems to be inapplicable. Phagocytic function shown by R.E. system must be considered to be powerless at viral infection. Moreover it will bring a result of spreading virus in the body. But R.E. system seems to show a very wide action to body defence. Thus the duties of R.E. system on virus susceptibility well be left as an important problem to be solved.

(We should be considered that, in general, virus material which using experiment is not purified virus particle only.)

Antopol (21) and Malomut et al (22) had already admitted that the atrophy of spleen and lymph tissues was the most remarkable anatomical changes caused by cortisone. This meaning on the mechanism of action of cortisone is the problem to be studied along with hypofunction of R.E. system. (Concerning this problem will be reported on later.) 
Cortisone has an intimate relation with the sugar metabolism. Ingle (23) observed an appearance of hyperglycemia and glycosuria by injecting 5 to $10 \mathrm{mg}$ of cortione daily to rat. But an effective administration of cortisone to increase the susceptibility does not show significant effect on blood sugar level until 72 hours after the administration and we were unable to observe any remarkable effect on serum protein directly.

\section{SUMM ARY}

In this report, we have made clear that the susceptibility of mice to the mouse encephalomyelitis virus was markedly increased when mice were treated with effective dose of cortisone. 1) Multiplication of the virus in the brain was promoted. 2) Appearance of dermal inflammatory reaction by turpentine oil was delayed but an obvious effect on the cellular reaction in the brain when the virus remarkably multiplied could not be observed and it was known, in general, that appearance of the cellular reaction was slow compared with the rate of multiplication of the virus. 3) Phagocytic function of subcutaneous tissue cell decreased. 4) Antibody formation decreased but the mechanism of promoting the multiplication of virus preceded this, and gave no effect on the existing antibodies. 5) Anatomically the atrophy of spleen and whole lymphnodes was remarkable. 6) No direct change on blood sugar level was observed regardless of infection with the virus. No immediate remarkable effect on serum protein was observed, but the rise of globulin following the infection could not be confirmed among the mice treated with cortisone.

Therefore, when the way of thinking about the susceptibility is divided into the following two, the receptivity and the vulnerability, effect of cortisone which increases the susceptibility is to increase the receptivity which allows the multiplication of pathogenic microorganism and the vulnerability which rises the symptom, on the contrary, seems to be decreased.* The hypofunction of R.E. system following the atrophy of spleen is the subject to be thoroughly searched in explaining the mechanism of the action of cortisone. It seems that there are still doubtfull points to be explained in the relation of the susceptibility to virus and the meaning mentioned above. (These points will be reported later).

\footnotetext{
* This fact seems to be correspondent to the symptom masking effect which cortisone shows clinically but we should like to warm that we should be cautious when use cortisone to infectious disease, especially when use cortisone alone.
} 


\section{REFERENCES}

(1) $\mathrm{K}_{\mathrm{AND}}$, Y.: Studies on the influence upon the susceptibility of mice to virus. (I report), Virus, Vol. 5, 36-41, 1955. (in Japanese.)

( 2 ) Southan, C. M., and Вавсоск, V. I. : Effects of cortisone, related hormaones, and adrenolectomy on susceptibility of mice to virus infections., Proc. Soc. Exp. Biol. and Med., Vol. 78, 105-109, 1951.

(3) Smith, J. M., Murphy, J. S., and M:rick, G. S.: Effect of adrenal hormone on infection of mice with pneumonia virus of mice (PVM)., Proc Soc. Exp. Biol. and Med., Vol. 78, 505$510,1951$.

(4) Shwartzman, G., and Fisher, A.: Alteration of experimental poliomyelitis infection in the Syrian hamster with the aid of cortisone., J. Exp. Med., Vol. 95, 347-362, 1952.

(5) Kawakita, Y.: Filtrable pathogenic organism., 78, 1951, Igazushoin. (in Japanese.)

(6) Michaed, M. Jr., and Whorton, C.M.: Delay of the early infammation response by cortisone., Proc. Soc. Exp. Biol. and Med., Vol. 76, 754-756, 1951.

( 7 ) Castor, C. W., Baker, B. L., Ingle, D. J., and LI, C. H.: Effect of treatment with ACTH or cortisone on anatomy of the brain., Proc. Soc. Exp. Biol. and Med, Vol. 76, 353-357, 1951.

( 8 ) Germutr, F. G. Jr., and Otrinaer, B.: Effect of 17-hydroxy-11-dehydrocorticosterone (compound E) and of ACTH on Arthus reaction and antibody formation in the rabbit., Proc. Soc. Exp Biol. and Med., Vol. 74, 815-823, 1950.

(9) Overman, J. R., and Hanan, R.: Effect of cortisone on mumps antibody formation in rabbits., Proc. Soc. Exp. Biol. and Med., Vol. 83, 427-430, 1953.

(10) Hays, S. P.: The effect of cortisone on local antibody formation, J. Immunol., Vol. 70, 450 - 453, 1953.

(11) Bjorneboe, Morgens, Fished, Edward, E., and Stoerk, Herbert, C.: The effect of cortisone and adrenocorticotrophic hormone on the concentration of circulating antibody., J. Exp. Med., Vol. 93, 37-47, 1951.

(12) Malkies, S., and Hargis, B. J.: The effect of ACTH and cortisone on the quantitative pretipitation reaction., J. Immunol., Vol. 69, $217-221,1952$.

(13) Fishel, E. E., Vanghan, J. H., and Рноторoulos, C.: Inhibition of rapid production of antibody by cortisone., Proc. Soc. Exp. Biol. and Med., Vol. 81, 344-348, 1952.

(14) Gray, W.D., Pedrick, Z., and Winne, R.: Effect of cortisone an anaphylactic response of guinea pig ileum., Proc. Soc. Exp. Biol. and Med., Vol. 78, 679-683, 1951.

(15) Dougherity, T. F., Chase, J. H., and White, A.: Pituitary-adrenal cortical control of antibody release from lymphocytes., An explanation of the anamnestic response., Proc. Soc. Exp. Biol. and Med., Vol. 58, 135-140, 1945.

(16) Chass, J. H., White, A., and Dodgherty, T. F.: Enhancement of circulating antibody concentration by adrenal cortical hormones., J. Immunol., Vol. 52, 101-112, 1946.

(17) Oуама, A.: Immunological and biochemical studies on the adrenal cortex hormone., NISSHIN IGAKU, Vol. 39, 346-256, 1952. (in Japanese.) 
(18) Reis \& Gотнe: Reticuloendothel und Korticotroper Wirkung., Endocrinology, Vol. 19, 148, 1931.

(19) UMEHARA, S.: Effect of adrenal cortex hormone on the function of R.E. system., ACTA HAEMATOLOGICA JAPONICA, Vol. 15, 200, 1952. (in Japanese.)

(20) Thomas, L.: Cortisone and infection., Annals New York Academy of Sciences, Vol. 56, $799-814,1953$.

(21) Antopol, W.: Anatomic change produced in mice treated with excessive doses of cortisone., Proc. Soc. Exp. Biol. and Med., Vol. 73, 262-265, 1950.

(22) Molomut, N., Spain, D. M., and Haber, A.: The effect of cortisone on the spleen in mice., Proc. Soc. Exp. Biol. and Med., Vol. 73, 416, 1950.

(23) Ingle, D. J.: The production of glycosuria in the normal rat by means of 17-hydroxy-11dehydrocorticosteron., Endocrinology, Vol. 29, 646, 1941.

(24) Selye, H.: Use of "granuloma pouch" technic in the study of antiphlogistic corticoids., Proc. Soc. Exp. Biol. and Med., Vol. 82, 328-333, 1953.

(25) Sugryama, T.: New study of blood and tissue and its way., 73-105, 1954, NANKODO. (in Japanese.) 
Photo. 1. Course of the inflammation produced by turpentine oil.

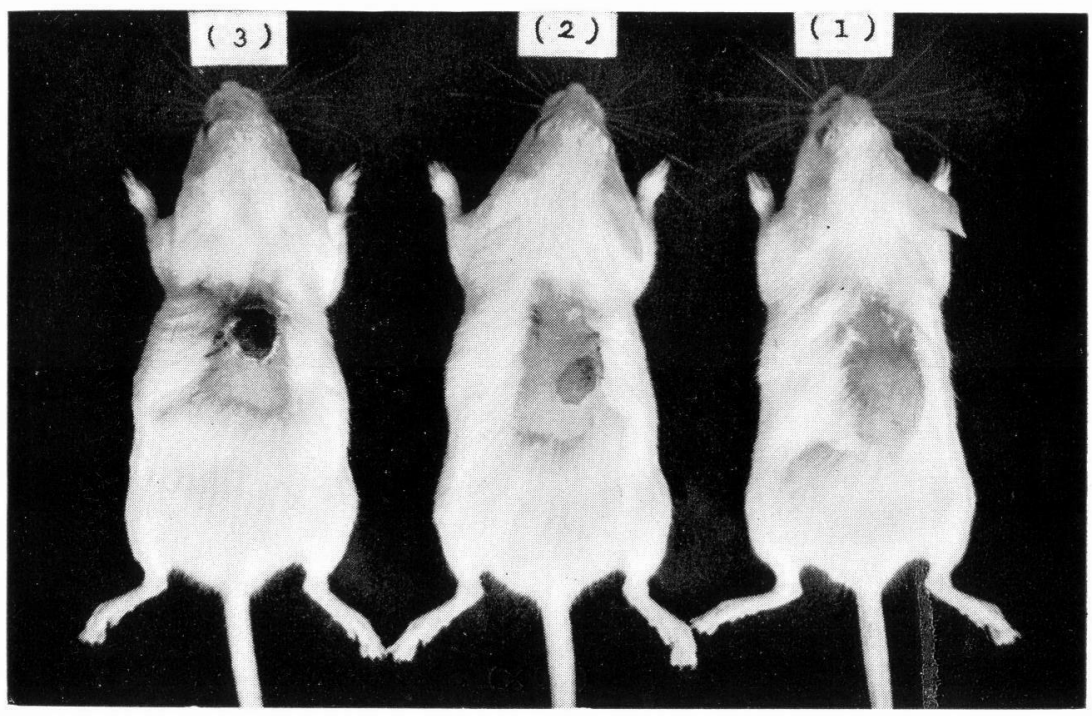

Photo. 2. Macroscopic change in the spleen of cortisone treated mice.

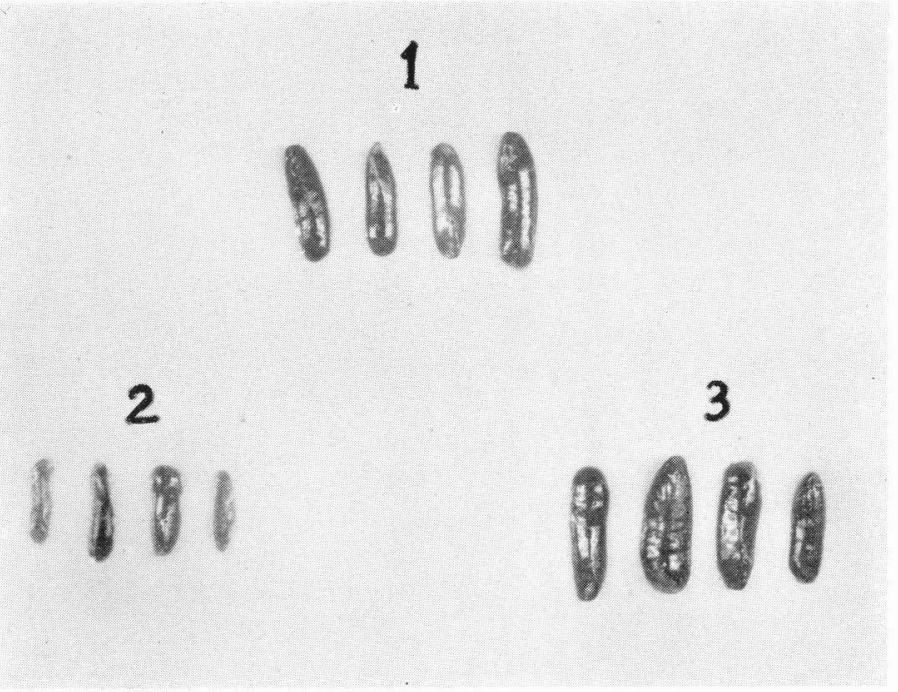

$1 \cdots$ Spleens of normal mice.

$2 \ldots$ Spleens of treated mice with cortisone.

3 ... Spleens of untreated mice but inoculated by virus. 
Photo. 3. Microscopic change in the spleen of cortisone treated mouse.

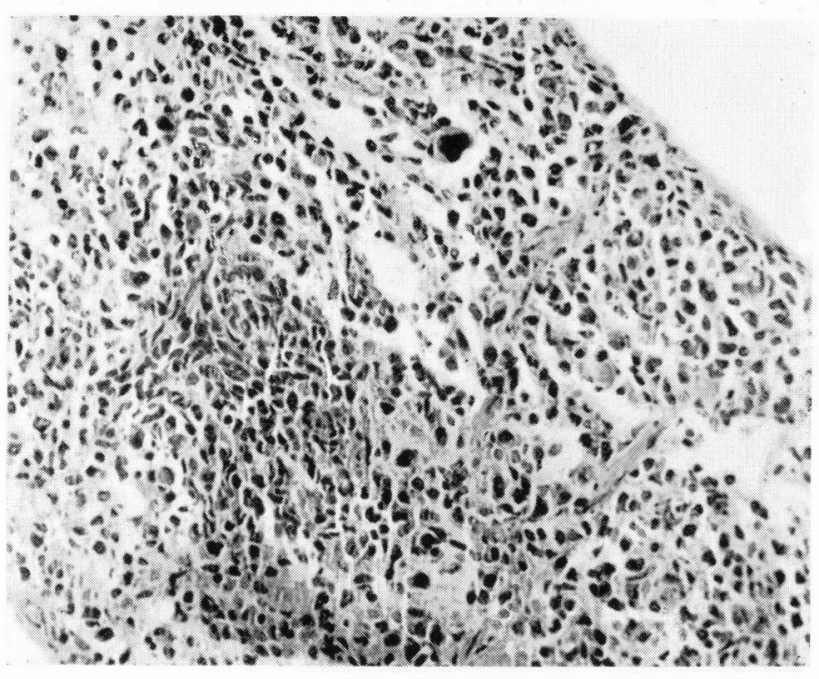

$(270 \times)$ 